Journal of Food Technology and Agroindustry Volume 3 No 1 Februari 2021

P-ISSN: 2656-0623

E-ISSN: 2684-8252

\title{
SIMULASI TRANSPORTASI TOMAT DAN PERUBAHAN MUTU TOMAT SELAMA PENYIMPANAN
}

\author{
Rozana $^{1}$, Daud Perdana ${ }^{2}$, Oktavia Nurmawaty Sigiro ${ }^{3}$ \\ Politeknik Negeri Sambas, Sambas (Indonesia) \\ rozanatunggadewi@gmail.com
}

\begin{abstract}
Chemical, physical, and microbiological damage of fruits and vegetables can occur during the transportation process. The percentage of damage can reach 30-50\% if the treatment during transportation is not carried out properly. The research objective was to determine the quality changes in tomatoes after transportation simulation based on the arrangement of the fruit in cardboard packaging. The treatment in this research is tomato arrangement patterns: the face centered cubic (FCC) arrangement, the traditional arrangement and the jumble (farmer) arrangement. The research begins with a transportation simulation using a vibrating table in a vertical direction, using a frequency range of $3.9 \mathrm{~Hz}$ and an amplitude of $5.2 \mathrm{~cm}$. The simulation is carried out in 1 hour. After the simulation at the 1st hour, amount of mechanical damage (bruising) on every package was carried out. The results showed that the pattern of arranging tomatoes in cardboard packaging that gave the least damage was the FCC arrangement pattern. The FCC pattern only causes shrinkage of $0.11 \%$ and the smallest amount of mechanical damage (bruising) is $0.64 \%$.
\end{abstract}

Kata Kunci: quality; arrangement pattern; transportation simulation; tomato

\begin{abstract}
ABSTRAK
Kerusakan kimiawi, fisik, dan mikrobiologis pada buah dan sayur dapat terjadi selama proses transportasi. Persentase kerusakan dapat mencapai 30-50\% jika perlakuan selama pengangkutan tidak dilakukan secara tepat. Tujuan penelitian untuk mengetahui perubahan mutu pada tomat setelah simulasi transportasi berdasarkan pola susunan buah dalam kemasan karton. Perlakuan penelitian ini adalah pola penyusunan tomat: pola penyusunan face centred cubic (FCC), pola penyusnan tradisional, dan pola penyusunan jumble (petani). Penelitian dimulai dengan melakukan simulasi transportasi menggunakan meja getar pada kisaran frekuensi $3.9 \mathrm{~Hz}$, amplitudo 5,2 cm dan dilakukan pada arah vertikal. Simulasi dilakukan dalam 1 jam. Setelah simulasi pada jam ke-1, dilakukan perhitungan jumlah kerusakan mekanis (memar) pada masingmasing kemasan. Hasil penelitian menunjukkan bahwa pola penyusunan tomat dalam kemasan kardus yang memberikan kerusakan paling minimal adalah pola penyusunan FCC. Pola FCC hanya menyebabkan susut sebesar $0.11 \%$ dan jumlah kerusakan mekanis (memar) paling kecil yaitu sebesar $0.64 \%$.
\end{abstract}

Keywords: mutu; pola susunan; simulasi transportasi; tomat 
Journal of Food Technology and Agroindustry Volume 3 No 1 Februari 2021

P-ISSN: 2656-0623

E-ISSN: 2684-8252

\section{PENDAHULUAN}

Dalam kegiatan pascapanen, transportasi adalah mata rantai yang pokok. Persentase kerusakan pada produk hortikultura seperti sayuran, buah-buahan, dan bunga potong dapat mencapai $30-50 \%$ jika penanganan pascapanen tidak dilakukan secara tepat. Saat pengangkutan dari kebun ke tempat pemasaran, kerusakan mekanis (memar) sangat banyak ditemui dan hal tersebut memicu kerusakan lainnya.

Menurut Darmawati (1994), penyebab utama kerusakan buah selama pengangkutan adalah amplitudo jalan. Amplitudo jalan yang rendah ditunjukkan seperti jalan dalam kota dan jalan aspal. Sedangkan amplitudo jalan yang lebih besar seperti jalan luar kota dan jalan buruk berbatu.

Kerusakan buah dan sayur yang dikemas selama transportasi dapat berupa kerusakan kimiawi, fisik, dan mikrobiologis. Perubahan warna buah (discoloration) menunjukkan adanya kerusakan kimiawi sedangkan buah dan sayur yang terinfeksi mikroorganisme ditandai dengan busuk (karat). Menurut Waluyo et al., (1996), tanda adanya kerusakan fisik dapat berupa adanya kulit yang terkelupas (pecah), memar, dan luka pada buah. Kerusakan-kerusakan tersebut disebabkan karena selama transportasi ada benturan (shock) dan getaran (vibration), beban tekanan pada buah (stress), varietas buah, tingkat kematangan buah, berat dan ukuran buah, karakteristik kulit buah, serta kondisi lingkungan selama transportasi.

Penelitian mengenai transportasi produk hortikultura telah dilakukan oleh Iswahyudi et al., (2015) pada komoditas jambu air camplong, Ngcobo et al., (2013) meneliti komoditas anggur, Sharan et al., (2009) pada komoditas tomat, (Darmawati, 1994; Purba dan Haloho, 2013) pada komoditas jeruk, brokoli (Anwar, 2005), jambu biji (Pradnyawati, 2006), mentimun (Kusumah, 2007).
Simulasi transportasi dilakukan dengan mengemas jeruk dalam kemasan karton bergelombang, disimulasikan dalam waktu 8 jam, pada frekuensi $6 \mathrm{~Hz}$ dan pada amplitudo $5 \mathrm{~cm}$. Kondisi ini mewakili jalan beraspal sepanjang $2490 \mathrm{~km}$ (setara pengangkutan antar pula Jawa dan Sumatera), atau mewakili transportasi di jalan berbatu sepanjang $905 \mathrm{~km}$. Hasil simulasi menghasilkan 5.74\% kerusakan pada buah (Darmawati, 1994).

Pada penelitian Anwar (2005), dilakukan simulasi transportasi pada komoditas brokoli menggunakan frekuensi $3.33 \mathrm{~Hz}$, amplitudo $5.31 \mathrm{~cm}$, simulasi selama 1 jam. Kerusakan brokoli paling rendah pada brokoli yang dikemas kardus karton dengan bahan pengisi kertas koran yaitu sebesar $8.46 \%$. Kerusakan brokoli paling tinggi yaitu sebesar $23.70 \%$ pada brokoli yang dikemas kantong plastik tanpa bahan pengisi.

Pengemasan dengan karton berbahan pengisi koran utuh yang membungkus buah satu per satu dapat mempertahankan mutu fisik jambu biji selama simulasi transportasi. Simulasi transportasi dilakukan pada kisaran frekuensi 3.31-3.35 Hz, amplitudo 3.49-3.97 $\mathrm{cm}$. Jambu biji dapat bertahan selama ditransportasikan selama 1 jam, 2 jam, dan 3 jam (Pradnyawati, 2006).

Kerusakan mekanis selama pengangkutan mentimun dari Cianjur ke Jakarta yang diwakili dengan simulasi transportasi pada frekuensi $2.59 \mathrm{~Hz}$, amplitudo $2.5 \mathrm{~cm}$ selama 3 jam yang dikemas dalam kardus karton meberikan dampak kerusakan mekanis lebih kecil (26.10\%) dibandingkan dengan mentimun yang dikemas dengan peti kayu (40.915\%).

Kerusakan mekanis selama transportasi yang merupakan dampak getaran dan beban kompresi yang diterima produk selama transportasi dapat dikurangi dengan cara melakukan pengemasan yang tepat (Pathare dan Opara, 2014). Maka dari itu, selama proses transportasi, perlu diperhatikan perlakuan 
terhadap komoditas yang didistribusikan karena peluang terjadinya kerusakan akibat transportasi sangat besar. Menurut Iswahyudi et al., (2015), perbaikan pengemasan mampu menekan kerusakan produk hortikultura selama transportasi.

Salah satu faktor yang harus diperhitungkan dalam perancangan kemasan adalah pola pengaturan produk dalam kemasan. Penelitian ini bertujuan untuk mengetahui perubahan mutu pada tomat setelah simulasi transportasi berdasarkan pola susunan buah dalam kemasan karton.

\section{METODE}

Bahan yang digunakan adalah tomat dengan ukuran dan tingkat kematangan yang relative seragam, sehat, tidak cacat atau luka. Alat yang digunakan kemasan karton, timbangan digital, refraktometer, Rheometer, chromameter, alat Simulasi Transportasi Meja Getar, timbangan, refraktometer, dan rheometer. Penelitian ini menggunakan Rancangan Acak Lengkap (RAL) dengan perlakuan pola penyusunan tomat yaitu pola penyusunan face centred cubic (FCC), pola penyusnan tradisional, dan pola penyusunan jumble (petani). Pola penyusunan tomat disajikan pada Gambar 1.

Prosedur penelitian dimulai dari buah tomat yang telah disortasi disusun dalam kemasan karton dengan pola FCC, jumble dan tradisional. Di dalam kemasan kardus karton, tomat diatur dengan susunan lurus 3 lapis dengan penempatan sampel pada tiap lapisannya. Simulasi transportasi dilakukan dengan menggunakan meja getar. Kemasan tomat secara bersama-sama diatur di atas meja getar. Simulasi transportasi dilakukan pada arah vertikal dengan kisaran frekuensi $3.9 \mathrm{~Hz}$ dan amplitudo $5,2 \mathrm{~cm}$. Simulasi dilakukan dalam 1 jam. Setelah simulasi pada jam ke-1, dilakukan perhitungan jumlah kerusakan mekanis pada setiap kemasan. Setelah simulasi produk disimpan selama 3 hari dan diukur mulai hari ke-0, hari ke-2, sampai hari ke-3. Pengukuran yang dilakukan meliputi, pengukuran susut bobot, kekerasan, dan total padatan terlarut. Sampel diukur dari hari ke-0 sampai hari ke-3 setelah simulasi pada suhu ruang.
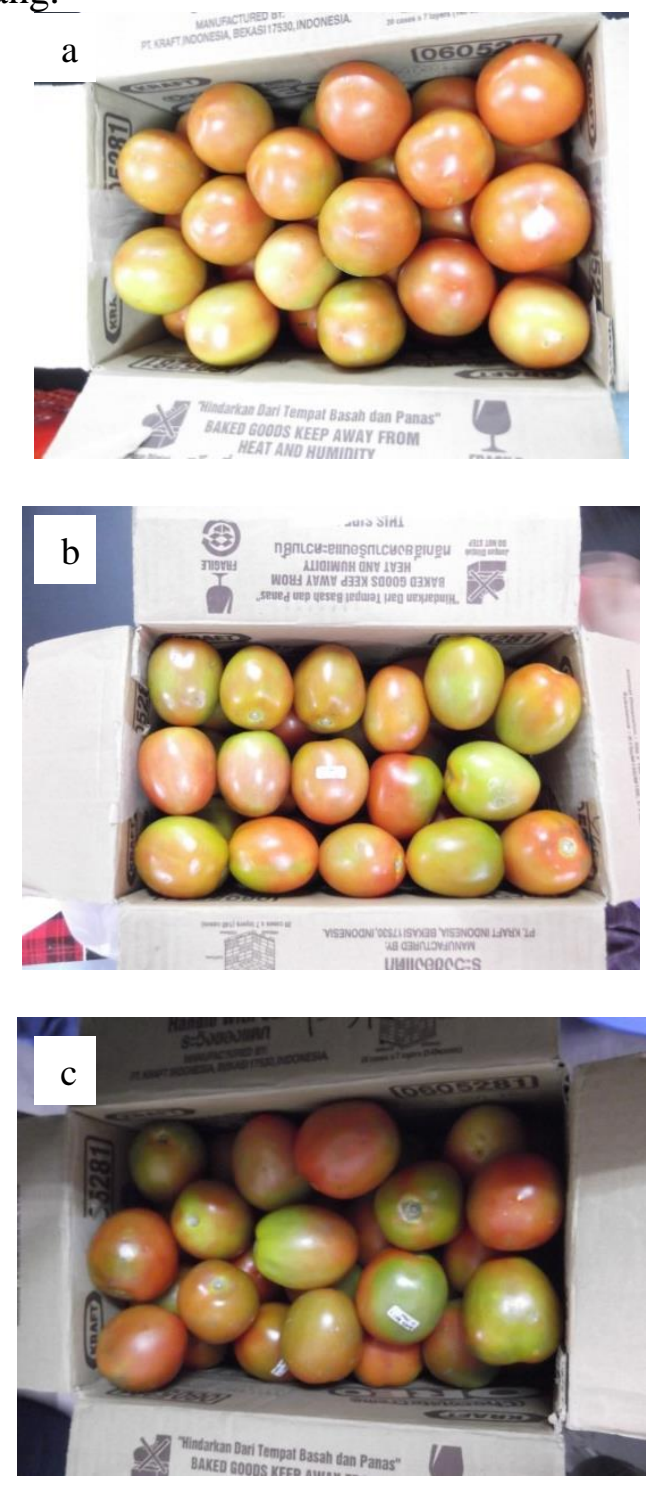

Gambar 1. Pola Penyusunan Tomat (a) Pola Penyusunan FCC, (b) Pola Penyusunan Tradisional, (c) Pola Penyusunan Jumble

Pengamatan mutu yang dilakukan setelah dilakukan simulasi transportasi adalah:

a. Susut Bobot 
Menghitung susut bobot menggunakan persamaan berikut:

$$
\text { susut bobot }=\frac{\mathrm{BA}-\mathrm{BK}}{\mathrm{BA}} \times 100 \%
$$

dimana : Susut bobot (\%)

BA : Berat awal (g)

BK : Berat akhir (g)

\section{b. Kekerasan Buah}

Kekerasan buah tomat diukur dengan alat rheometer. Satuan untuk tingkat kekerasan bahan adalah Newton (N). Pengukuran kekerasan dilakukan pada tiga titik yang berbeda dan dirata-ratakan. Beban maksimum yang diberikan adalah $10 \mathrm{~kg}$, kedalaman 10 $\mathrm{mm}$, dengan laju beban turun $30 \mathrm{~mm} /$ menit.

\section{c. Total Soluble Solid (TSS)}

TSS atau total padatan terlarut diukur menggunakan alat Refraktometer dan dinyatakan dalam satuan ( ${ }^{\circ}$ Brix). Pada refraktometer diletakkan cairan daging buah. Hasil yang tertera menunjukan kadar total padatan terlarut $\left({ }^{\circ}\right.$ Brix) yang mewakili tingkat kemanisan.

\section{d. Persentase kerusakan (memar)}

Setelah tomat disimulasikan segera dilakukan uji tingkat kerusakan mekanis berdasarkan ada tidaknya luka memar dan luka goresan pada kulit buah. Pengujian dilakukan secara visual. Jumlah kerusakan dalam satu kemasan dihitung dengan persamaan:

$$
\% \text { rusak }=\frac{\text { Jumlah rusak }(\text { buah })}{\text { Total sampel }} \times 100
$$

\section{HASIL DAN PEMBAHASAN}

\section{Susut Bobot Tomat}

Hasil pengamatan susut bobot tomat setelah dilakukan simulasi dan disimpan selama e hari disajikan pada Gambar 2.

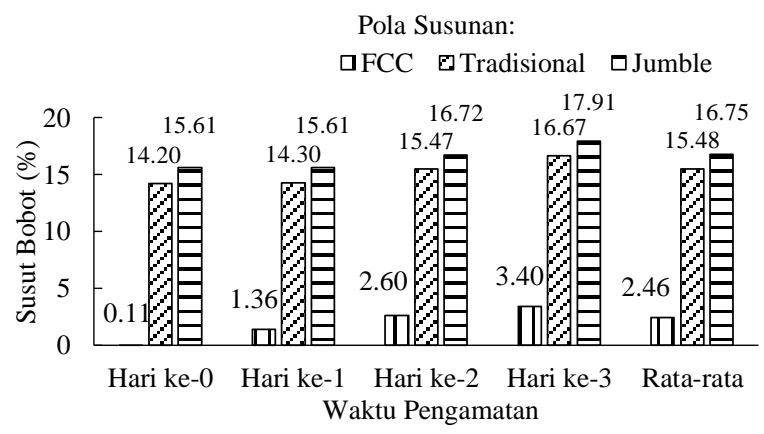

Gambar 2. Perubahan susut bobot tomat selama penyimpanan

Penurunan bobot tomat terjadi pada semua metode penyusunan. Susut bobot setelah simulasi transportasi merupakan pengukuran bobot tomat sebelum dilakukan penilaian kerusakan dan penilaian kekerasan. Persentase susut bobot pasca simulasi transportasi (hari ke-0) terkecil terdapat pada pola penyusunan FCC yaitu sebesar $0.11 \%$ dan susut bobot terbesar terdapat pada pola jumble yaitu sebesar $15.61 \%$. dengan rata-rata $2.46 \%$, sedangkan persentase susut terbesar pada pola penyusunan jumble dengan rata-rata $16.75 \%$.

Berdasarkan Gambar 2, dapat diketahui bahwa selama penyimpanan perubahan berat produk terjadi pada semua pola penyusunan tomat dalam kemasan dan persentase kehilangan berat tersebut semakin meningkat selama penyimpanan sampai hari ke-3. Perubahan berat tersebut disebabkan karena hilangnya kandungan air pada produk.

Tingginya persentase susut bobot pada pola penyusunan jumble menggambarkan tingkat kerusakan yang terjadi pada pola penyusunan tersebut. Hal ini berlaku juga untuk persentase susut bobot terendah yaitu pada pola penyusunan FCC yang menggambarkan tingkat kerusakan pada pola FCC juga rendah. Kerusakan pada pola penyusunan jumble dikarenakan kedudukan buah dalam kemasan tidak kompak, sehingga intensutas gesekan dan benturan antara buah menjadi lebih tinggi berbeda halnya dengan buah yang disusun dengan pola FCC yang 
memiliki susunan buah dalam kemasan lebih kompak (Yulianti et al., 2009).

Susut bobot pada tomat yang mengandung 92-93\% air terjadi karena proses respirasi dan transpirasi yang dialamu buah tomat sehingga kandungan airnya berkurang. Pengurangan berat/susut juga disebabkan karena terurainya pati dan glukosa menjadi karbohidrat dan air yang disebut dengan proses hidrolisis pati. Tingginya aktivitas transpirasi disebabkan hilangnya lapisan lilin pada buah akibat kerusakan pada kulit buah. Menurut Utama (2002), memar pada permukaan buah memberikan peluang keluarnya air. Kerusakan mekanis pada permukaan yang relatif besar meningkatkan laju penguapan dan kehilangan air. Laju perpindahan uap air melalui pori-pori di permukaan buah disebabkan adanya perbedaan temperatur dan kelembaban relatif (RH) antara atmosfer internal buah dengan atmosfer lingkungan di sekelilingnya.

Menurut Chakraverty dan Singh 2001 dalam Anwar 2005), kehilangan air merupakan penyebab langsung kerusakan tekstur (kelunakan), kerusakan kandungan gizi, kelayuan, dan pengerutan. Dampak getaran mesin, kehilangan kadar air, penanganan kasar selama bongkar muat yang diterima buah selama transportasi dapat mempengaruhi mutu fisik, tekstur, dan nilai gizi tomat.

\section{Kekerasan Buah}

Perubahan kekerasan buah tomat setelah simulasi transportasi dan selama penyimpanan dilakukan pada tiga titik berbeda dalam satu buah yang sama. Sebelum dilakukan simulasi transportasi, rata-rata kekerasan buah tomat adalah 2.04 N. Hasil pengamatan kekerasan buah tomat disajikan pada Gambar 3.

Pola Susunan:

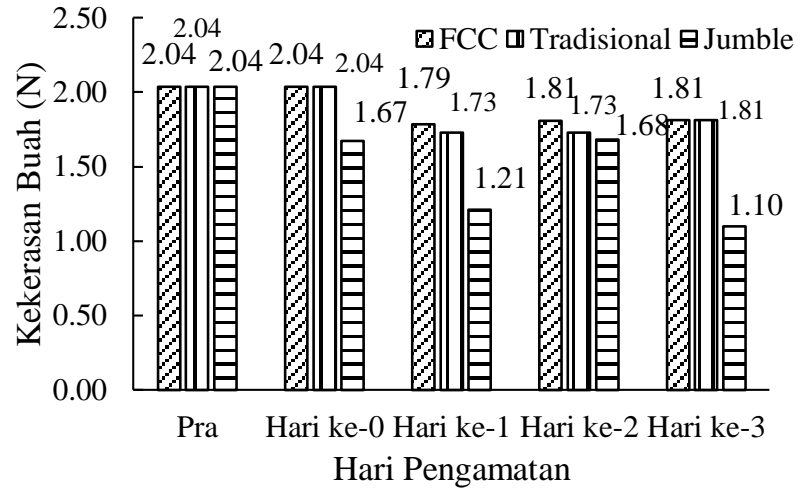

Gambar 3. Perubahan kekerasan buah tomat selama penyimpanan

Berdasarkan Gambar 3, dapat dilihat bahwa terjadi penurunan kekerasan buah tomat selama penyimpanan. Pola penyusunan yang menunjukkan penurunan hingga hari ke-3 terbesar kekerasan buah adalah pola penyusunan jumble $(1.10 \mathrm{~N})$ jika dibandingkan dengan pola penyusunan tradisional $(1.81 \mathrm{~N})$ dan pola penyusunan FCC $(1.81 \mathrm{~N})$. Tingkat kekerasan yang tinggi menunjukkan bahwa tingkat kekerasan juga tinggi (keras), jika tingkat kekerasan rendah menunjukkan kekeasan buah rendah (lembut). Hal ini berkaitan dengan penusukan jarum rheometer pada permukaan buah tomat. Semakin keras buah tomat yang diamati, maka gaya yang dibutuhkan untuk menusukkan jarum akan semakin besar sehingga hasil pengukuran tinggi.

Tingkat kekerasan tomat berhubungan dengan tingkat kerusakan mekanis (memar) karena getaran saat transportasi. Buah tomat yang mengalami benturan akan lembek dan lembut ketika ditekan. Kekerasan buah tomat menurun selama proses penyimpanan hingga hari ke-3. Perubahan kekerasan tersebut disebabkan perubahan fisiologis buah selama penyimpanan yaitu karena komposisi dinding sel yang berubah (WInarno, 2002). Selain itu juga disebabkan karena adanya penguapan air (Pantastico, 1989). 
Tingkat kekerasan pada buah tergantung pada tebalnya kulit luar, kandungan total zat padat dan kandungan pati yang terdapat pada bahan. Ketegaran buah juga akan berkurang karena melemahnya dinsing sel yang diakibatkan oleh larutnya kandungan pektat dan pektinat. Hal tersebut terjadi saat buah memasuki fase pematangan.

Selain karena proses pematangan buah, pelunakan pada buah juga disebabkan proses transpirasi dan respirasi setelah pemanenan, sehingga tekanan turgor semakin kecil dan menyebabkan buah menjadi lunak. Penguapan air pada sel menyebabkan sel menciut sehingga ruangan antar sel menyatu dan zat pektin menjadi saling berikatan.

Dinding sel tersusun atas zat pektin dan karbohidrat. Jika terjadi depolimerisasi karbohidrat dan zat pektin maka dinding sel dan ikatan kohesi antar sel akan melemah sehingga viskositas sel menurun dan tekstur tomat menjadi lunak (Muhtadi, 1992). Kekerasan buah tomat dipengaruhi oleh kekuatan dinding sel, semakin lemah dinding sel makan kekerasan buah akan semakin rendah.

\section{Total Padatan Terlarut (TPT)}

Kandungan total padatan terlarut setelah simulasi transportasi dan selama penyimpanan mengalami perubahan. Hasil pengamatan total padatan terlarut pada tomat selama penyimpanan disajikan pada Gambar 4.

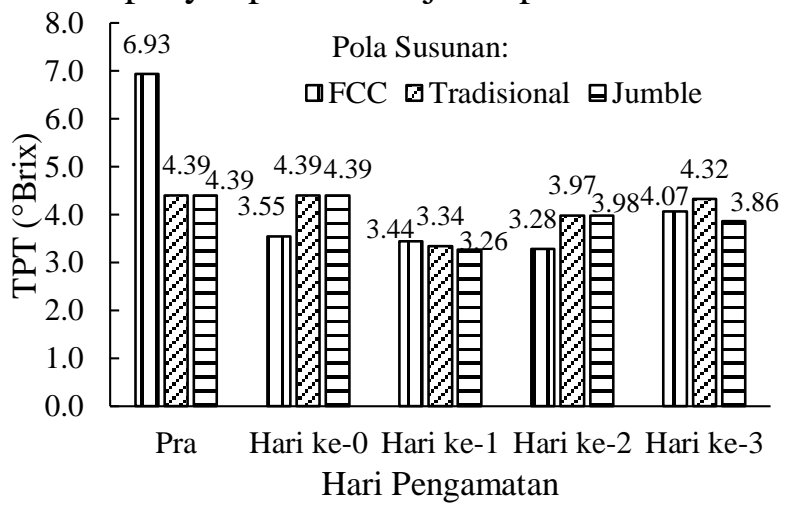

Gambar 4. Total padatan terlarut buah tomat setelah simulasi transportasi dan selama penyimpanan

Berdasarkan Gambar 4, dapat dilihat bahwa total padatan terlarut pada tomat berflutuatif. Kondisi ini disebabkan perbedaan sampel yang diuji setiap harinya. Pada dasarnya tingkat kemanisan tomat tidak mengalami perubahan yang signifikan, dikarenakan tomat termasuk ke dalam jenis komoditas berkadar pati rendah. Peningkatan kemanisan dapat terjadi dimungkinkan karena penurunan kadar air sehingga konsentrasi gula akan meningkat.

\section{Tingkat Memar (Kerusakan Mekanis)}

Tingkat kerusakan mekanis dihitung berdasarkan jumlah buah yang rusak pada tiap pola susunan (kemasan). Buah tomat dikatakan rusak apabila ditemukan kondisi kulit buah yang melesak ke dalam (penyok). Selain itu juga diamati kondisi jaringan daging buah yang lembek. Kemudian jaringan daging buah akan berubah warna menjadi cokelat. Selain daging buah yang lembek, kerusakan mekanis ini juga menyebabkan kulit buah tomat menjadi lembut ketika ditekan. Hasil pengamatan tingkat memar (kerusakan mekanis) tomat setelah simulasi transportasi disajikan pada Gambar 5.

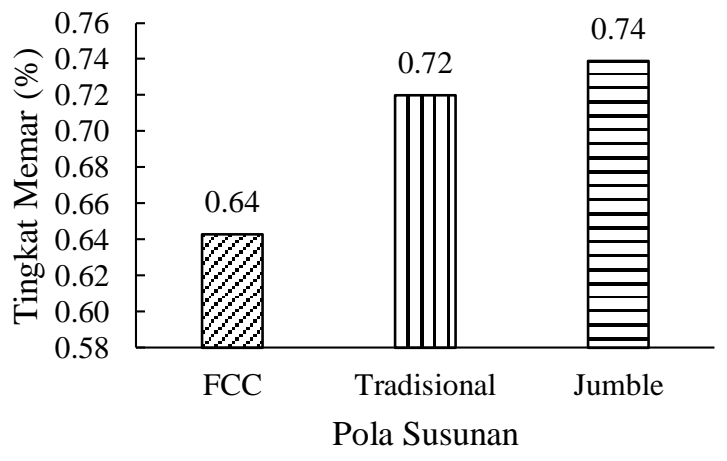

Gambar 5. Tingkat Kerusakan Mekanis (Memar) pada Tomat setelah Simulasi Transportasi 
Berdasarkan Gambar 5, dapat dilihat bahwa tingkat kerusakan mekanis terbesar dihasilkan oleh pola penyusunan jumble $(0.74 \%)$, dan kerusakan mekanis terkecil adalah pada pola penyusunan FCC (0.64\%). Fluktuasi amplitudo dan frekuensi saat simulasi yang menggambarkan kondisi jalan juga mempengaruhi persentase kerusakan mekanis (memar) pada tomat.

Menurut Soleimani dan Ahmadi (2014), tingkat kerusakan produk secara signifikan dipengaruhi oleh getaran saat transportasi berlangsung. Jenis suspensi, kecepatan perjalanan, kondisi jalan, dan fitur kemasan merupakan faktor yang mempengaruhi tingkat getaran. Tingkat getaran yang diterima buah dan sayur selama transportasi berbeda-beda tergantung kendaraan transportasi yang digunakan. Lu et al., (2010) menyatakan bahwa tingkat guncangan dan getaran yang dihasilkan selama transportasi berlangsung dipengaruhi oleh kecepatan mobil.

Rendahnya kerusakan pada kemasan dengan pola penyusunan FCC dikarenkan goncangan yang terjadi selama proses transportasi tidak memberikan pengaruh yang besar terhadap susunan buah dalam kemasan. Buah yang disusun dengan pola FCC memiliki kedudukan yang kompak. Tingginya kerusakan pada pola penyusunan tradisional dan jumble disebabkan banyaknya celah antar buah dalam kemasan sehingga buah saling berbenturan dan terjadi lompatan kecil berulang yang mengakibatkan kerusakan mekanis (memar).

Menurut Yulianti et al., (2009), rendahnya kerusakan pada pola penyusunan FCC, selain disebabkan kondisi susunan buah yang kompak juga dipengaruhi oleh jumlah bidang sentuh (contact point) yang terjadi antar buah. Jumlah bidang sentuh antar buah pada pola FCC lebih banyak dibandingkan dengan pola penyusunan lainnya sehingga jumlah beban dapat tersebar secara merata diseluruh permukaan buah dan jumlah beban yang diterima menjadi lebih kecil.

Beban yang diterima tomat sehingga menyebabkan kerusakan adalah beban tekan yang dapat berupa tumpukan dan benturan selama transportasi. Reaksi terhadap beban tekan tersebut menyebakan memar pada tomat. Perubahan bentuk (deformasi) pada daging buah disebabkan oleh tekanan tersebut dan disesuaikan dengan kemampuan menahannya. Deformasi merupakan penyempitan dinding sel daging buah karena adanya tekanan. Penyempitan dinding sel menyebabkan meningkatnya tekanan turgor sel daging buah tomat dan mendesak keluarnya air dari dalam sel daging buah tersebut.

Tekanan (compression) yang diterima buah semakin bertambah jika isi kemasan terlalu penuh (over packing) dan penumpujan kemasan terlalu tinggi. Isi kemasan yang terlalu penuh maupun yang terlalu kurang (under packing) juga menjadi penyebab kerusakan fisik pada produk. Kemasan yang terlalu kurang menyebabkan buah saling berbenturan dan terlempar akibat getaran selama transportasi.

\section{KESIMPULAN}

Berdasarkan pembahasan dapat disimpulkan bahwa pola penyusunan tomat dalam kemasan kardus yang memberikan kerusakan paling minimal adalah pola penyusunan FCC. Pola FCC hanya menyebabkan susut sebesar $0.11 \%$ dan jumlah kerusakan mekanis (memar) paling kecil yaitu sebesar $0.64 \%$.

\section{DAFTAR PUSTAKA}

\footnotetext{
Anwar, RS. 2005. Dampak Kemasan dan Suhu Penyimpanan Terhadap Perubahan Sifat Fisik dan Masa Simpan Brokoli Setelah Transportasi. Skripsi. Fakultas Teknologi Pertanian, Institut Pertanian Bogor.

Darmawati E. 1994. Simulasi Komputer untuk Perancangan Kemasan Karton Bergelombang dalam Pengangkutan Buah-buahan. Tesis. Program Studi Keteknikan Pertanian, IPB. Bogor.
} 


\section{Journal of Food Technology and Agroindustry Volume 3 No 1 Februari 2021}

P-ISSN: 2656-0623

E-ISSN: 2684-8252

Iswahyudi, Darmawati E, Sutrisno. 2015. Perancangan Kemasan Transportasi Buah Jambu Air (Syzygium aqueum) cv Camplong. Jurnal Keteknikan Pertanian (1) no. $1: 65-72$

Kusumah, E.S. 2007. Pengaruh Berbagai Jenis Kemasan dan Suhu Penyimpanan Terhadap Perubahan Mutu Fisik Mentimun (Cucumis sativus L.) Selama Transportasi. Skripsi. Departemen Teknik Pertanian, IPB, Bogor.

Lu, F., Y. Ishikawa, H. Kitazawa, T. Satake. 2010. Effect of Vehicle Speed on Shock and Vibration Levels on Truck Transport. Journal Packaging Technology and Science 23: 101-109.

Muchtadi, D. Petunjuk Laboratorium Fisiologi Pasca Panen Buah-buahan dan Sayur-sayuran. Bogor: PAU Pangan dan Gizi IPB.

Ngcobo, M.E.K., M.A. Delele, U.L. Opara, C.J. Meyer. 2013. Performance of Multi-Packaging for Table Grapes Based on Airflow, Cooling Rates and Fruit Quality. Journal of Food Engineering 116: 613-621.

Pantastico, ER.B. 1989. Fisiologi Pasca Panen, Penanganan dan Pemanfaatan Buah-buahan dan Sayuran Tropika dan Sub Tropika. (Diterjemahkan oleh Kamariayani; editor Tjitrosoepomo). Yogyakarta: Gadjah Mada University Press.

Pathare, P.B., Opara, L. Umezuruike. 2014. Structural Design of Corrugated Boxes for Horticultural Produce: A Review. Biosystems Engineering 125: 128-140.

Pradnyawati, P. I. 2006. Pengaruh Kemasan dan Goncangan Terhadap Mutu Fisik Jambu Biji. Skripsi. Departemen Teknik Pertanian, IPB. Bogor.

Purba T, J.D Haloho. 2013. Teknologi Berbagai Kemasan terhadap Mutu Buah Jeruk Siam dan Jeruk Keprok Terigas. Prosiding Seminar Nasional Pekan Inovasi Teknologi Hortikultura Nasional: Penerapan Inovasi Teknologi Hortikultura dalam Mendukung Pembangunan Hortikultura yang Berdaya Saing dan Berbasis Sumberdaya Genetik Lokal. lembang 5 Juli 2012. ISBN 978-979-8257-49-0

Sharan, G.S., K.P. Srivastav, Rawale, U. Dave. 2009. Development of Corrugated Fiber Board Cartons for Long Distance Transport of Tomatoes in India. International Journal for Service Learning in Engineering 4(1); 31-34, Springer 2009. ISSN 1555-9033

Soleimani B, E. Ahmadi. 2014. Evaluation and Analysis of Vibration During Friut Transportation as A Function of Road Conditions, Suspension System and Travel Speeds. Engiineering in Agriculture, Environment and Food. ISSN $1881-8366$
Utama I M. 2002. Horticulture Post Harvest Technology. (in Bahasa Indonesia). Assessment Center for Tropical Fruits Udayana University. Bali

Waluyo SB, Aminarsih D, Sanntausa S. 1996. Teknik Pengemasan Buah Nenas dalam Kemasan Karton untuk Mempertahankan Mutu Segarnya. Jurnal Hortikultura. 6(3):287-302.

Winarno. FG. 2002. Fisiologi Lepas Panen Produk Hortikultura. M-Brio press. Bogor

Yulianti N, Sutrisno, Darmawati E. 2010. Improvement of the Technology Packaging for the Transportation of Mangosteen. Jurnal Keteknikan Pertanian Vol. 24(1): 5560 